statement of the Vinaya Pitaka may be viewed in connexion with the fact that the Buddhists never denute the $\bar{a} j \bar{\imath} v i k a s$ as real followers of Gosāla. Thus it might perhaps obtain some little more probability.

After all, I have only wished with these few remarks to try to prove that $\vec{a} j \bar{\imath} v a k a$ originally had nothing to do with Gosāla especially, but was a much older name designating a sect to which he originally belonged and afterwards transferred to his discipies.

Jarl Charpentier.

\title{
Imprecations in Indian Land Grants
}

On pp. 248 ff. of this Journal for 1912 Mr. Pargiter has published a useful collection (increased afterwards by Professor Hultzsch, p. 476) of those passages from the Mahābhārata and from the Purānas to which some of the well-known imprecatory and benedictory verses quoted in ancient Sanskrit grants of land may ultimately be traced. Most of the earliest grants themselves either state, in a general way, that these verses were composed or sung by Vyāsa or Veda-Vyāsa, the reputed compiler of both the Mahābhārata and the Purānas, or declare more distinctly that they were proclaimed by Vyāsa in the Mahābhārata.

In connexion with this subject, it may perhaps be mentioned that the fabulous Vyāsa is regarded as the author of a much quoted Smrti or law-book as well, and that it is to this legal writer named Vyāsa that the authorship of the imprecations in the grants has been attributed in Dr. Burnell's Elements of South Indian Palcengraphy, p. 114, where he says: "The last clause in most grants consists of imprecations on those who resume or violate them; and these generally consist of the words from the Vyāsasmrti given above, though often with considerable variations." The reference is to a previous passage in Dr. Burnell's Palæography, containing the whole chapter 
on documents from the Smrrticandrika an the original Sanskrit, and in it a text of Vyāsa: saștivarșasahasrāṇi dānācchedaphalam tatha| āgāminrpasāmantabodhanārtham nrpo likhet ||

Now it is important to note that the texts assigned to Vyāsa in the Smrrticandrikā and other digests of law include, besides the text just quoted, which agrees closely with one of the commonest imprecatory texts in the grants, a number of other verses in which all the more substantial parts of a grant are carefully enumerated. Further details are supplied in other Smrtis and in the commentaries, so that we may say, with Dr. Burnell, that the several clauses of a grant, which were legally necessary to its validity, are well described in the Indian law-books. Thus a proper copperplate grant is to contain-the place from which it is issued; the genealogy of the royal donor; a description of the gift, and of its conditions and boundaries; an address to royal officials and other persons; the information of future rulers regarding the gift and its preservation; its religious object; the name, caste, family, and Vedic study of the recipient or recipients; the perpetuity, inviolability, and heredity of the gift; special privileges granted; the benedictory and imprecatory verses; the signature of the king; the date; the official in charge of the grant; the royal seal. For a detailed comparison of these rules with the contents and wording of existing grants I may be allowed to refer to my paper on "Theory and Practice in Ancient Indian Procedure", ZDMG. xliv, 342 ff. (1890).

Would it be going too far, then, to credit some of the learned composers of Śāsanas, whose qualifications and acquirements are discussed in the curious Śāsanādhikāra (ii, 10) of the Arthaśāstra, with a general knowledge of the above rules, and therefore also of some of the verses on gifts of land occurring in the law-books? Thus the 
short Smrti of Bṛhaspati ${ }^{1}$ consists of eighty verses chiefly on gifts of land, sixteen of which actually recur in land grants. They commence as follows: phālakrsțtām

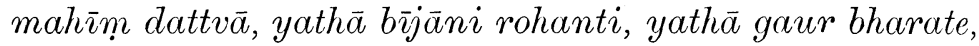
sainkham bhadrāsanam, ädityo varuno vahnih, āsphotayanti pitarah, bahubhir vasudhā, svadattām paradattām,

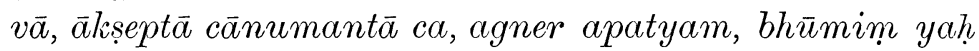
pratigrhnāti, sarveșām eva dānānām, harate hārayed

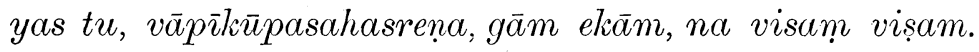
The śloka svadattām paradattām vā is also quoted as a Smṛti in Nandapaṇdita's Vaijayanti. The triștubh sāmānyo 'yam dharmasetuh̆ is both cited from Vyāsa in legal commentaries and quoted in many grants. Nor is Vyāsa the only authority for all these sayings even according to the grants, several of which introduce the verses on gifts of land by some such clause as tath $\bar{a}$ coktam dharmaśāstre (or dharmaśästreṣu), or uktam ca dharmaśāstraih, or uktam ca smrtiśāstre, or bhavanti cātra smrtiślokāh, or uktam ca mānave dharme, or udàharanti manvādayo maharșayah, or atra manugītāh śloka bhavanti, or tath $\bar{a}$ ca dharmaslok $\bar{a} h$, etc. ${ }^{2}$ Judging from these references the Dharmaśâstras or Smṛtis were certainly known to some writers of grants, and so it seems were the legal commentaries, one of which at least, the Dānakhanda of Hemādri (c. 1300 A.D.), is twice referred to in a grant as an authoritative work on gifts. ${ }^{3}$ The Dānakhanda is no doubt one of the most comprehensive works extant on $d \bar{a} n a$, and contains a section on gifts of land (bhümidāna, pp. 494 ff.) full of quotations from the Epics and from the Smrtis, in which we again meet with a number of verses familiar from the grants,

1 Dharmaśāstrasaṃgraha (Calc., 1876), i, pp. 644 ff. = Smṛtīnām Samuccayah (Puna, 1905), pp. $108 \mathrm{ff}$.

2 Ep. Ind., vol. iii, pp. 45, 343, 348, 353, 357; iv, p. 259 ; vi, pp. 18, 97, 145 ; vii, pp. 93,100 ; viii, p. 142 ; ix, pp. 45,276 ; xi, pp. 97,100 , etc.

3 Hemādridānāny akarot, Hemādridānavratī (Ep. Ind., vol. iii, p. 61). 
such as phālakrștām mahīṇ dattvā, ādityo varuno

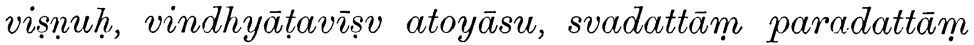
$v \bar{a}$, sasțivarșasahasrāṇi, āsphotayanti pitarah, etc.

These considerations tend to show that the law-books should not be overlooked as a possible source of some of the verses on gifts of land in the grants. It is not intended, however, to question the correctness of the statement that those verses, which are attributed to Vyāsa in grants of the Gupta period and later on, were taken from the ancient Epics rather than from the Vyāsasmrti, as suggested by Dr. Burnell. The Mahābhärata, as we have seen, is distinctly mentioned as the source of these verses in some of the grants. As regards the Purānas; we have, besides the verses actually traced by Mr. Pargiter to various Purānas, the express statement in several grants that the verses come from a Puranna, ${ }^{1}$ and a remark in such an authoritative legal work as the Vinramitrodaya (p. 194) to the effect that an imprecatory verse from the Purānas shall be inserted in the grants (șaștivarșasahasrāñ̄tyādi purānavacanaprasiddham ... svargädinarakādiphalam lekhayed rājety arthah).

WüRzBURG.

J. JoLLy.

March 21, 1913.

P.S. The additional two verses, which Mr. R. Narasimhachar has quoted on p. 388 of Journal for 1913 from a land grant of about 400 A.D., and traced to the

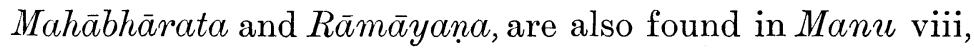
98, 99 .

\section{The Alcmanic Figure}

An interesting and ingenious attempt has been made of late by Mr. J. Fraser ${ }^{2}$ to bring the so-called Alcmanic

\footnotetext{
1 Purānavacanāni likhyante or bhavanti cātra paurānikāh ślokāh : Ep. Ind., vol. iii, p. 63 ; iv, pp. 109, 117 ; viii, p. 156, etc.

2 Classical Quarterly, iv, 27-9.

JRAS. 1913 